\title{
Errett H. Callahan (1937-2019): Researcher, flintknapper, and artist
}

\author{
Hugo G. Nami
}

CONICET-IGEBA, Laboratory of Geophysics "Daniel A. Valencio”, Department of Geological Sciences, FCEN, Universidad de Buenos Aires (UBA), Ciudad Autónoma de Buenos Aires, Argentina.

Email: hgnami@fulbrightmail.org

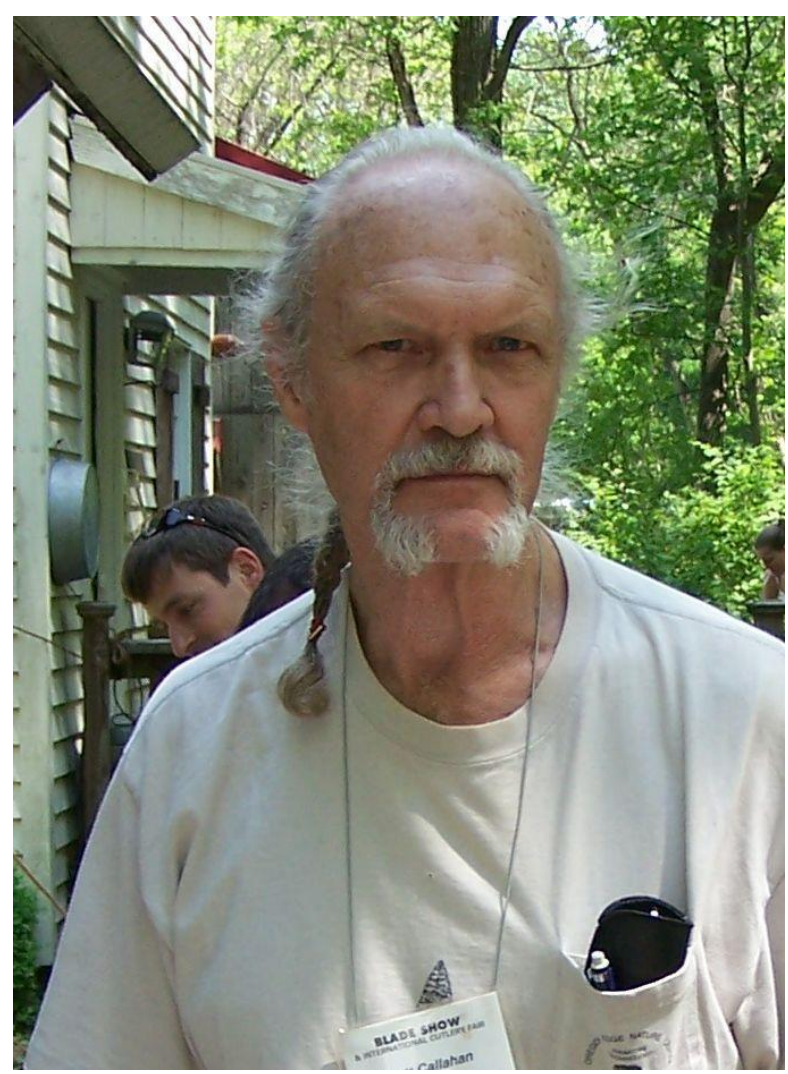

Errett Callahan in 2006 (Photo by Mercedes Nami).

Errett Hargrove Callahan Jr. was a standout American pioneer in experimental archaeology, lithic technology, and replicative experimental studies. Errett, son of Errett Callahan, Sr. and Mary Ingraham Callahan, was born on December $17^{\text {th }}, 1937$ in Lynchburg, Virginia, where he lived until his death on May $29^{\text {th }}, 2019$. He leaves his son Tim, daughter Melody, and three grandchildren, Chris, Megan, and Ryan.

Published by the School of History, Classics and Archaeology, University of Edinburgh ISSN: 2055-0472. URL: http://journals.ed.ac.uk/lithicstudies/

Except where otherwise noted, this work is licensed under a CC BY 4.0 licence. 
Prior to college, Errett attended the Christ Church School in Virginia. His college education began at Hampden-Sydney College, in Hampden-Sydney Virginia from 1956 to 1960, where he majored in French, in preparation for missionary work that he hoped to do in West Africa after graduation. Instead, he became a free-lance artist and went to East Africa in 1965, where English was readily spoken. After returning to the United States he painted landscapes and taught at a prep school. From 1969 to 1973 he attended Virginia Commonwealth University in Richmond, VA, there he majored in painting and received his Master of Fine Arts. Callahan attended The Catholic University of America in Washington D.C. between 1974 and 1981 where he completed his Masters and Doctoral work, focused on experimentation and replication of aspects of Native American archaeology. During this time, he produced two important works. His published Master's thesis The Basics of Biface Knapping in the Eastern Fluted Point Tradition: A Manual for Flintknappers and Lithic Analysts, a detailed analysis of the stages of biface manufacture, which is widely referenced in the archaeological literature. His unpublished Doctoral dissertation, Pamunkey Housebuilding: an Experimental Study of Late Woodland Technology in the Powatan Confederacy, was the culmination of years of experimentation and research into the lifeways of the Powatan people. Callahan was awarded an Honorary Doctorate at Uppsala University in 1992 in recognition of his research on the Mesolithic and Neolithic eras in Sweden.

During Errett's childhood, he was a member of the Boy Scouts of America. Under the guidance of his father, a Scoutmaster, Errett was introduced to techniques for outdoor survival and the use of traditional weapons such as the bow and arrow. These experiences in learning skills of traditional techniques and technologies markedly influenced his research activities and scientific career. Callahan started to flake stone in 1956, teaching himself during the first decade by trial and error, by examining the archaeological artifacts he was trying to reproduce, and reading everything he could get on the subject. During the late 1960s through the 1970s, he met and learned from master knappers such as Don Crabtree, Gene Titmus, François Bordes, John B. Sollberger, and Jacques Pelegrin. Errett's interviews with most of these influential knappers were published between 1979 and 1980 in Flintknapper's Exchange - the first regular publication devoted to the subject - and Contract Abstract Archaeology in 1982.

In his career that spanned several decades, one thing that most distinguished Callahan was his ability and willingness to share his expertise with others. He taught several generations of flintknappers around the world and gave many lectures and demonstrations on lithic technology, and traditional techniques. While at Catholic University, Callahan taught anthropology at Virginia Commonwealth University where he pioneered the study of Living Archaeology (Coles 1979: 210-221; Watts 1997), teaching classes that combined academic study and research with primitive technological experimentation. From the 1970s on, Callahan shared his vast knowledge and skills in flintknapping with more than 1,000 students, through his summer courses, workshops and seminars at diverse institutions, including Virginia Commonwealth University (Richmond, Virginia), Malheur Field Station (Princeton, Oregon), Cahokia Mound Museum Society (Illinois), Lejre Research Center (Denmark), and since 1987, at his Cliffside workshops (Lynchburg, Virginia). Through his teaching, publications and demonstrations, he influenced and taught many professional and avocational archaeologists and survivalists. 

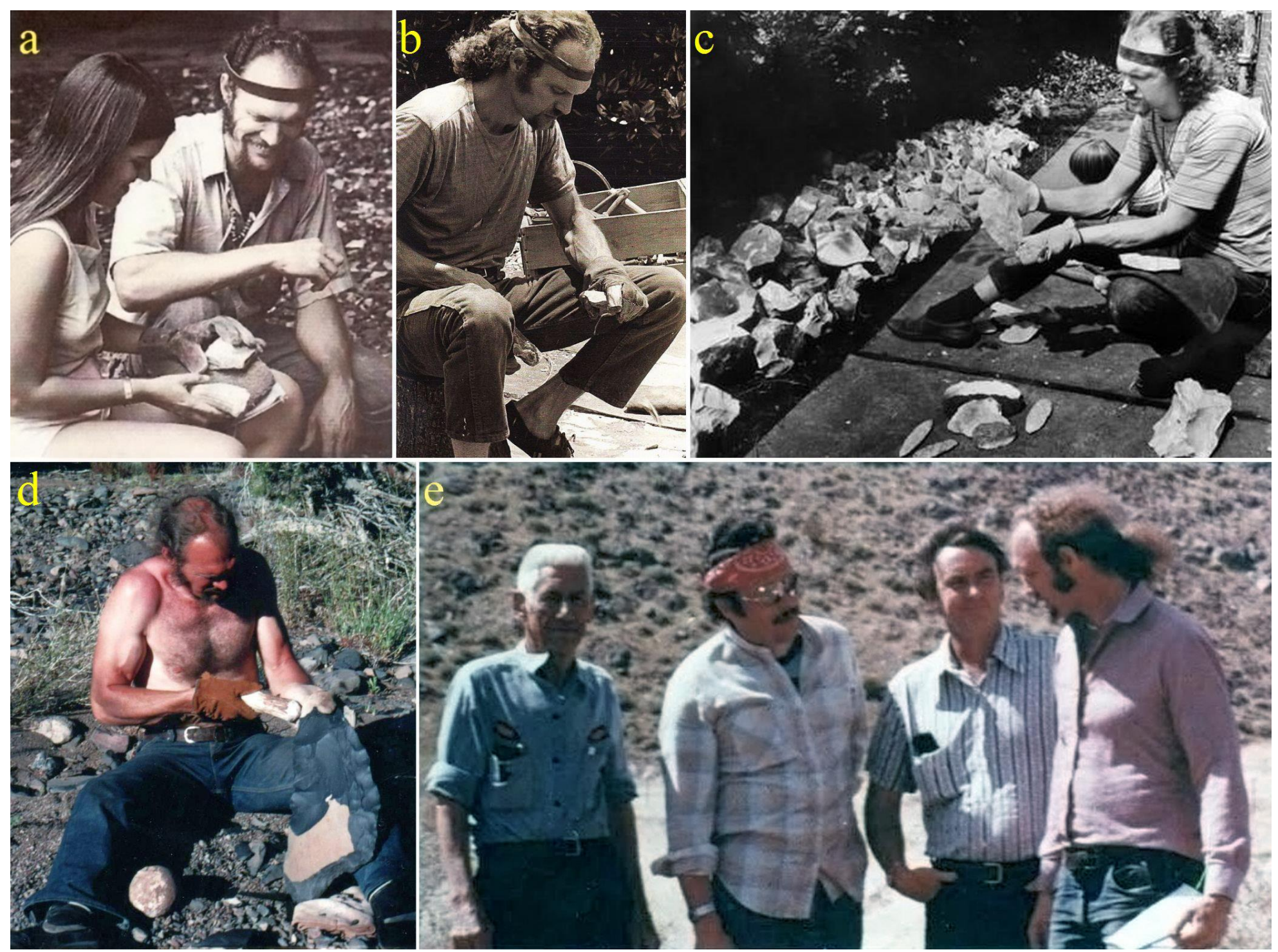

Figure 1. Errett during the 1970s. a) teaching flintknapping at Virginia Commonwealth University ), b-c) flaking and showing a biface, d) working a large basalt biface, e) from left to right, with J. Sollberger, J. Flenniken, and G. Titmus in 1978. (Photos by courtesy of R. Harwood.) 
Callahan was a rigorous scientific experimenter. His work not only focused on stone tool replication, but also on broad subsistence and experimental archaeology. He directed several Living Archaeology projects in the 1970s. There, while testing certain archaeological hypotheses, the participants lived off the land under survival conditions, from two to nine weeks, using only traditional techniques. In 1978 he took part in the legendary, pioneering and historic Ginsberg elephant butchering experiment, headed by Dennis J. Stanford at the Smithsonian Institution, Washington, D.C As part of the project, Callahan, an expert at throwing the atlatl, threw stone-tipped and bone-tipped spears into the carcass to test differences in penetration of the tool types.
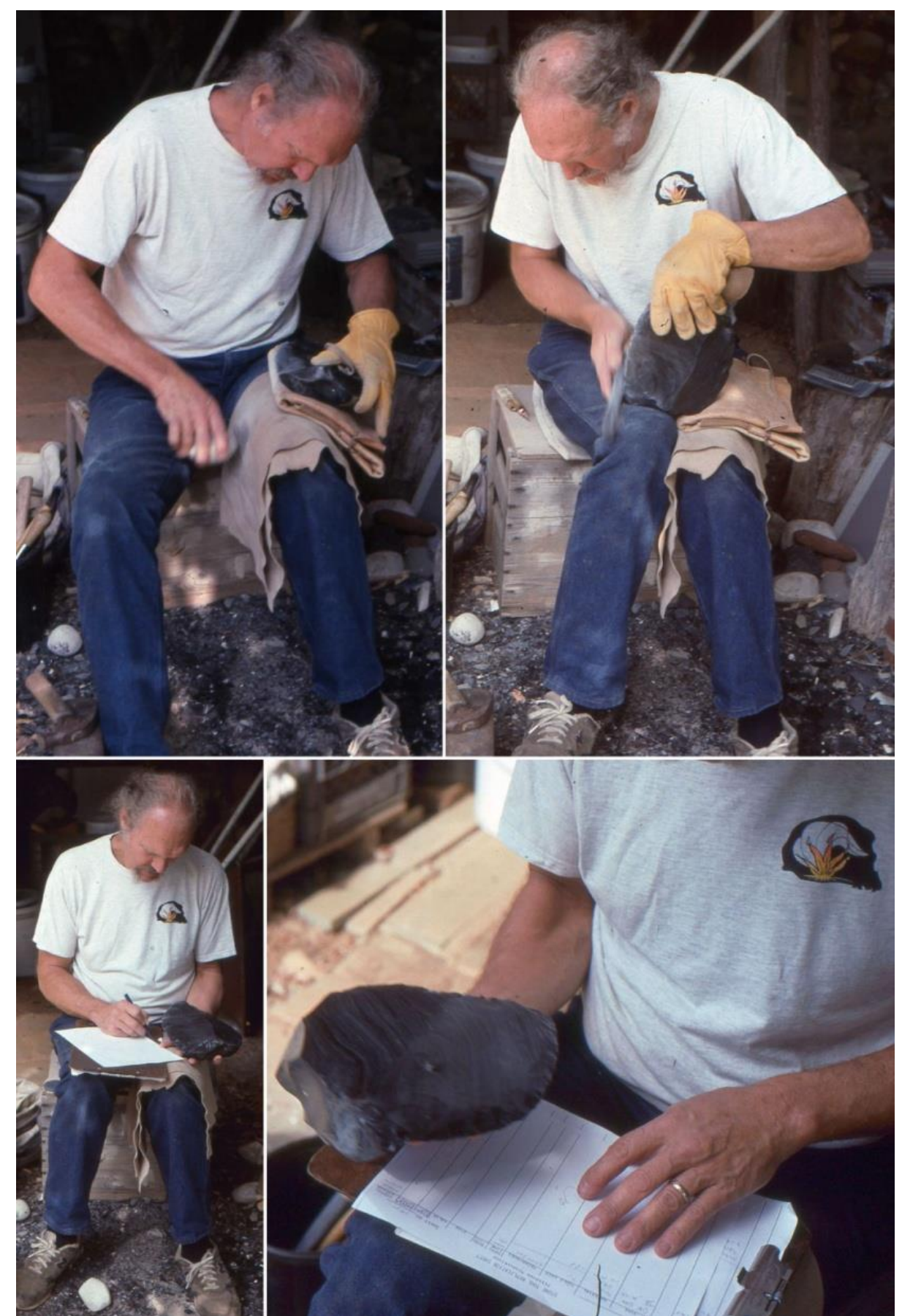

Figure 2. Errett showing the initial manufacturing stages of a Type IV Danish dagger and documentation of his work in 1995. (Photos by H. G. Nami.) 
Callahan was an active scholar and researcher of the archaeology of Scandinavia and in 1979 he began traveling extensively in Denmark and Sweden, where he performed experiments on Mesolithic and Neolithic topics. In 1981 he spent seven months at the Lejre Experimental Centre in Denmark at the invitation of its founder, Hans-Ole Hansen, conducting research into the techniques used to produce the stone tool kit, including Neolithic Danish daggers. This was the beginning of three decades of experimental research into the reduction sequence of Danish dagger production, which led to the publication of a major book on the topic. These investigations were supported by Piltdown Productions and by grants from the Danish American Council, the King of Sweden, the Lejre Research Center (Denmark), Jean and Ray Auel (Portland, Oregon), and Uppsala University (Sweden).

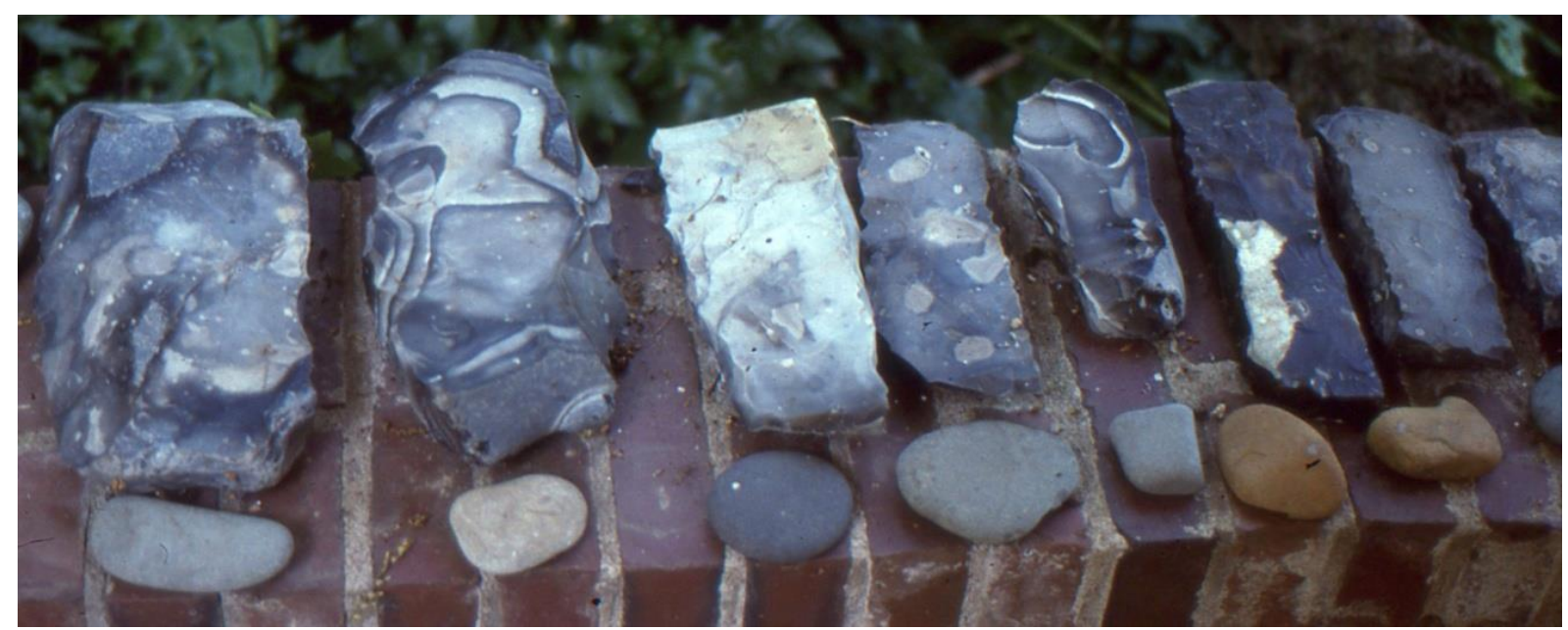

Figure 3. Early stages of manufacture and finished products of square edge Neolithic Danish axes. (Photo H. G. Nami.)

Callahan founded Piltdown Productions in 1981 to sell his many publications, flintknapping supplies, and instructional materials, as well as his stone tool replications and nontraditional knives. He produced obsidian scalpels for medical use that have been used with great success in hundreds of operations. In 1991 he was a founder and president of the board of the Society of Primitive Technology, to promote the practice and teaching of aboriginal skills, to foster communication between teachers and practitioners, and to set standards for authenticity, ethics, and quality. For 25 years its formal publication, the Bulletin of Primitive Technology, was a voice for those engaged in experimental/experiential archaeology and traditional technology.

Errett Callahan's work is well known to researchers and to people engaged in lithic technology and other traditional technologies. Over a span of more than 50 years, Callahan researched broad and wide-ranging topics, including ceramic manufacture, traditional weapons such as bows, arrows and spear-throwers, and especially flintknapping. These investigations resulted in his publication of several books and more than 200 articles, including many seminal papers that opened new aspects of experimental archaeology, house reconstruction, lithic analysis and stone tool reduction sequences. His publications reflect his prowess as a scientist, flintknapper, and artist. Those combined perspectives are evident in his many contributions devoted to understanding the human past. He was passionate and methodical in his scientific approach and artistic calling; inflexible in his values and persistence. 

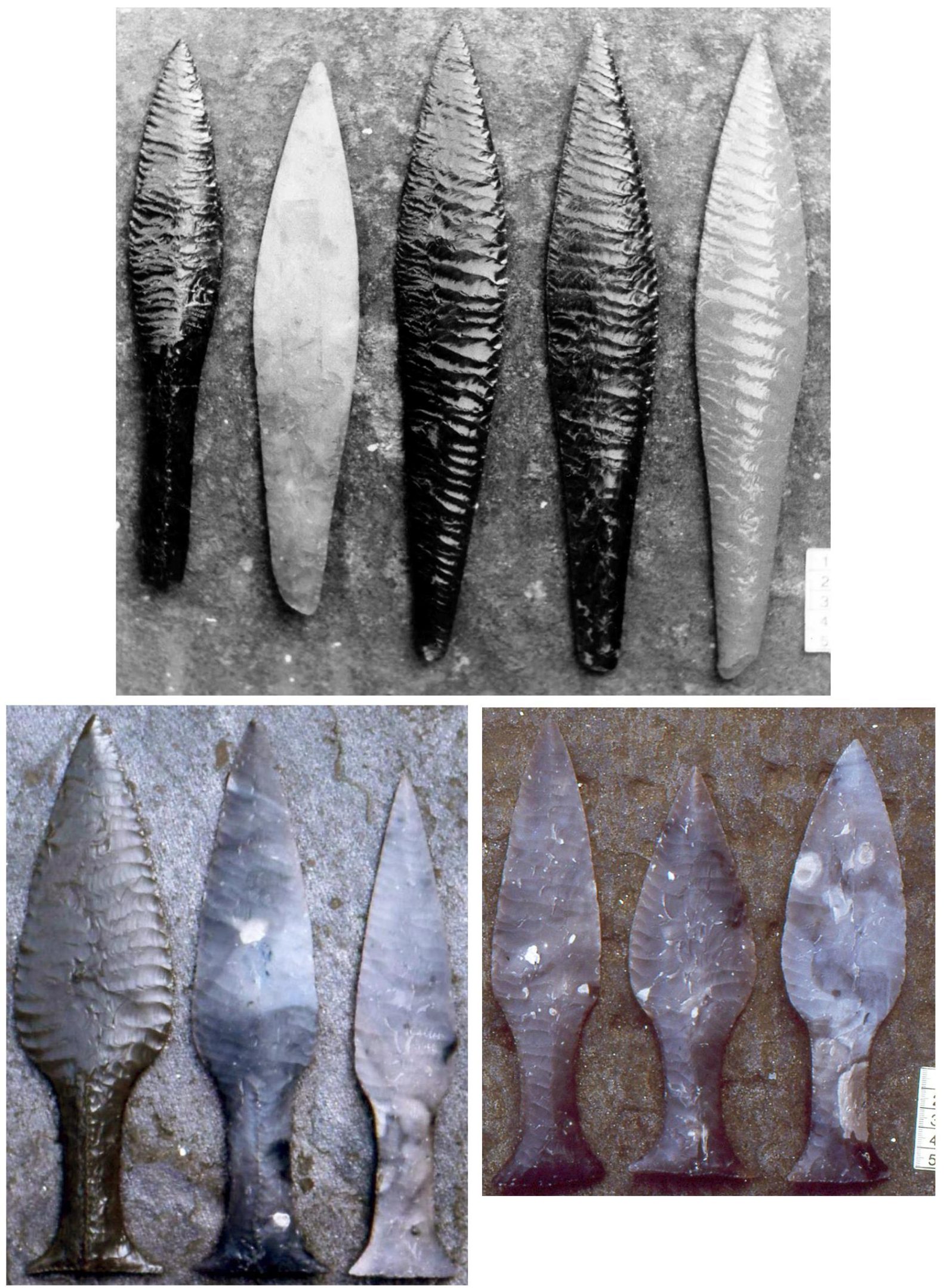

Figure 4. Illustrative examples of type Ic and IV Danish daggers replicas made by Callahan. (Photos by H. G. Nami.)

His flintknapping reached the highest standards of perfection and artistry. Over the first 25 years of his research, he investigated the lithic technologies of the European Paleolithic, 
American Paleo-Indian, Archaic, Woodland, and Scandinavian Mesolithic. Not content to stop there, he spent the next 30 years working his way through the complex stone technologies of the European Neolithic, mainly trying to understand the reduction of Scandinavian Neolithic daggers, particularly the prestigious Type IV Danish dagger. Discoveries that he made during his research of various lithic technologies fueled his creativity, leading to many original designs. By combining different techniques and styles of manufacture and prehistoric designs, such as Mesoamerican eccentrics and Neolithic flaking, he developed and created his own style of modern artistic knives for collectors. His work was a product of passion and unlimited expression. His broad range of experimental replication and his artistic creations have made him one of the most accomplished knappers in human history. He made about 10,000 stone tools, more than 1,000 knives, 227 ceramic pot replicas, 51 house reconstructions, and hundreds of bows and arrows. Each piece was systematically signed, numbered, drawn, and recorded in volumes of notebooks.

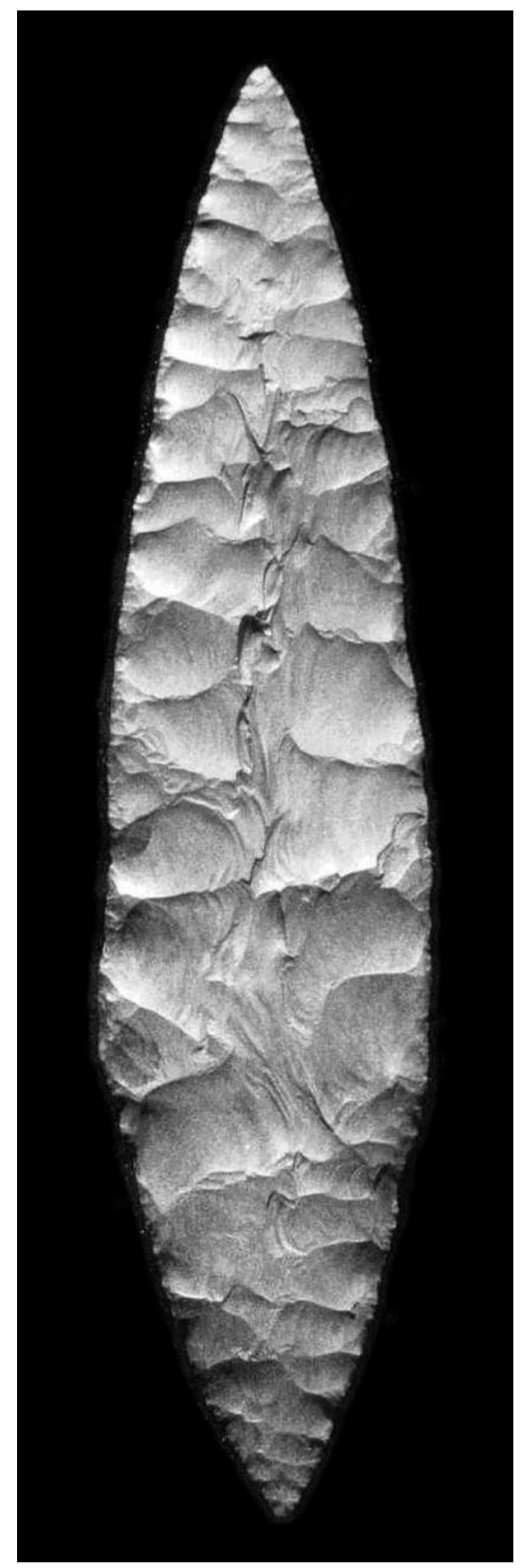

Figure 5. Solutrean laurel-leaf replica. (Photo by E. Callahan.) 


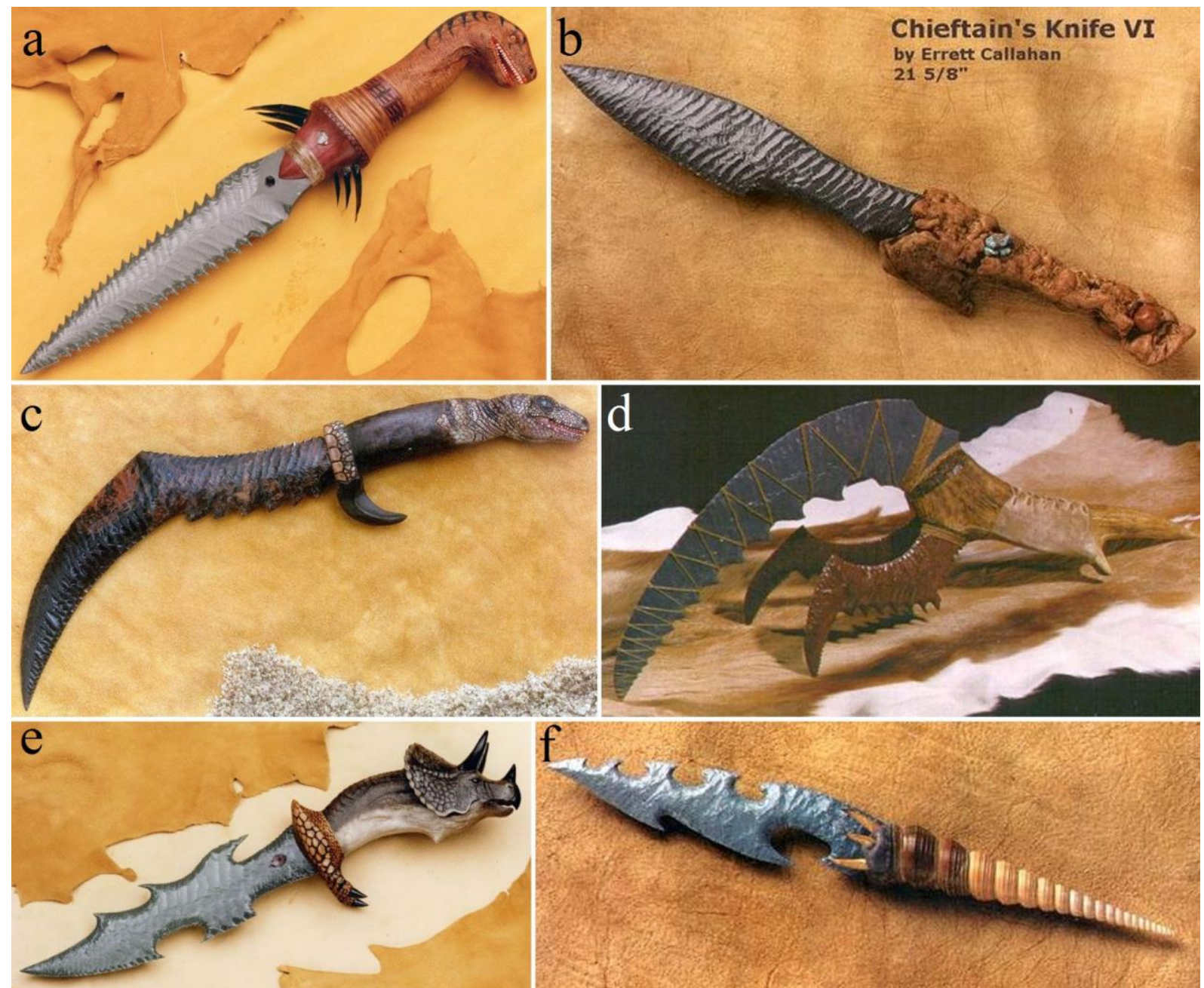

Figure 6. A sample of Callahan's artistic knives creations. a) Allosaurus, b) Chieftain's VI, c-d) Velociraptor I and III, e) Triceraptos, f) Neptune's. (Photos after Callahan 2019.)

Callahan's contributions were both theoretical and practical. Perhaps the most attractive aspect of his practical work is the level of perfection he reached with his stone tool replications. However, his theoretical ideas on experimental archaeology and lithic technology, and his commitment to ethical research and documentation, are equally important. He promoted a code of ethics for contemporary knappers encouraging them to sign and date their work, and was a champion for traditional knapping methods including the use of antler, stone, and bone knapping tools. Applying scientific thinking and artistic skill, he recorded his research activities through time-consuming documentation and realistic drawings. His meticulous documentation allows both comparisons with the archaeological record and intersubjective verification with other experimenters. This documentation is very useful for understanding a key concept in lithic analysis: variability.

Callahan has influenced and helped many knappers, primitive technologists, archaeologists, experimental archaeologists, and lithic analysts in their research. In appreciation and recognition of his worldwide contributions to anthropological sciences and archaeology, a festschrift in his honor was published in 2010 (Nami 2010). A large record of his publication can be found on the TDAR website (TDAR 2019). A selected list of Callahan's titles is presented at the end of this article. 

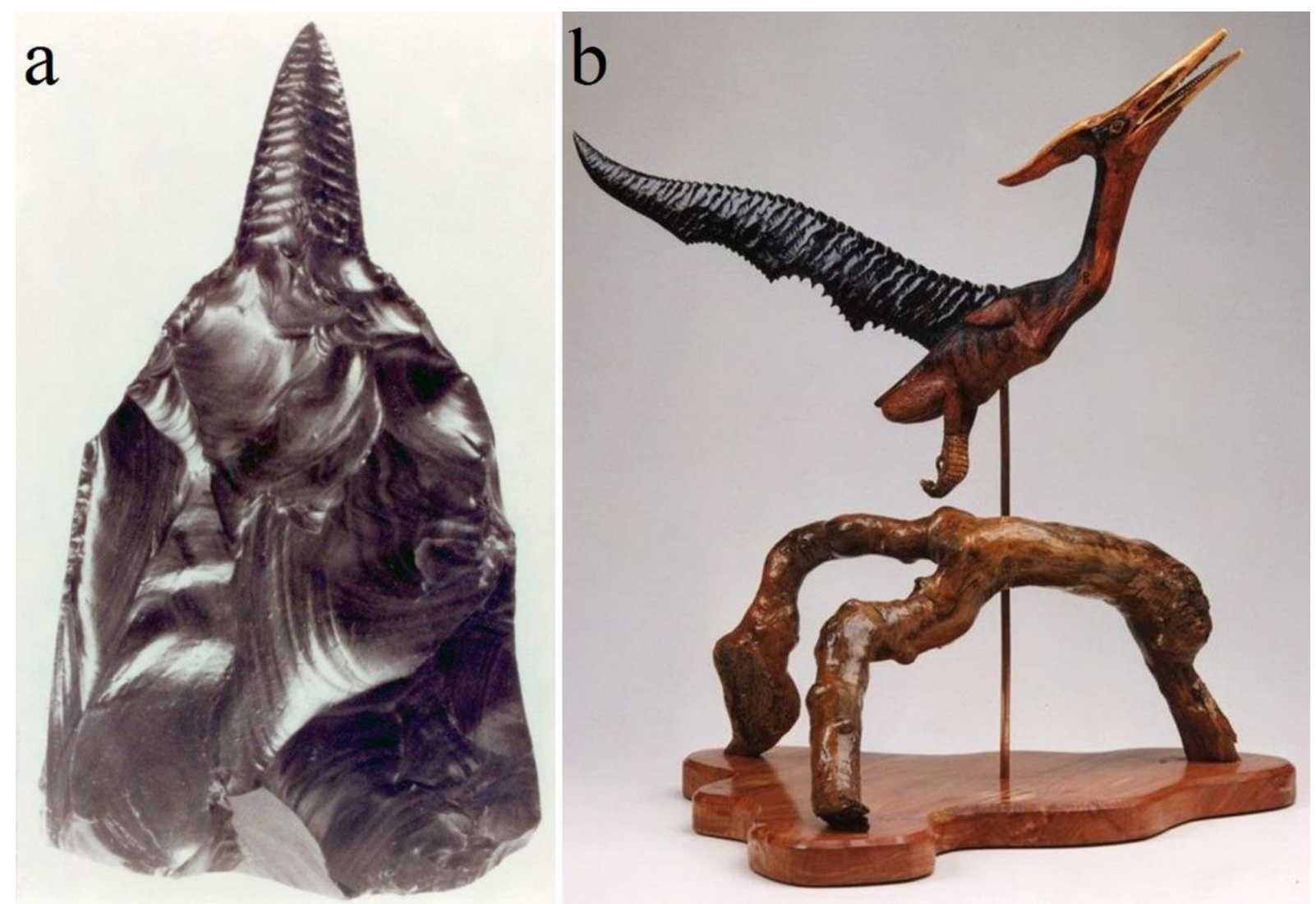

Figure 7. Sculptures/knives made by Errett Callahan. a) Sword in the stone (1996), b) Pterosaur (2002). (Photos from Callahan 2019.)

Callahan also received many honors; among them: Who's Who in the South and Southwest; Personalities of the South; Men of Achievement; Directory of Distinguished Americans; Personalities of America; International Who's Who of Contemporary Achievement; Book of Buffs, Masters, Mavens, and Uncommon Experts, and World Almanac. Resulting from his flaked artistic creations, Callahan received a number of awards in many knives shows in the USA, such as the Wooden Sword Award, the Best High Art Knife, and The Best Fantasy Knife.

Finally, Errett has been a great mentor, model, and friend. Our more than three decades of friendship started in 1981 or 1982 when I was working on an Early Holocene Patagonian projectile point reduction sequence from an experimental perspective. Experimental archaeology was largely a mysterious and unknown topic in this part of the world. At that time, some of the more powerful, conservative and reactionary members of the archaeological establishment were arguing that flintknapping as a research activity was a handicraft and a fruitless methodology. Given these attacks and destructive resistance, Errett's letters, as well D. Stanford and R. Bonnichsen, became fundamental to my continued exploration and work in experimental lithic and archaeological research in Argentina.

\section{Acknowledgements}

Acknowledgements go to Dan Stueber for requesting me to write this biography and for provided useful observations, help, and cooperation by editing the initial English version. Acknowledgements also go to Ray Harwood for providing me the pictures illustrated in Figure 1. 


\section{Selected publications by Errett Callahan}

Callahan, E.H., (director), 1972, Fluting. film on file at the Piltdown Productions Library, Lynchburg.

Callahan, E.H. 1973, The Old Rag Report: A Practical Guide to Living Archaeology. Department of Sociology and Anthropology, Virginia Commonwealth University, Richmond, 155 p.

Callahan, E.H. (Ed.) 1974, The APE. Experimental Archaeology Papers. Vol. 3. Department of Sociology and Anthropology, Virginia Commonwealth University, Richmond, 213 p.

Callahan, E.H. (1975). Flake removal sequence and cultural inference. presented at the Lithic Symposium: Recent Emphasis en Lithic Technology, 40th Annual Meeting, Society for American Archaeology, Dallas.

Callahan, E.H. (Ed.) 1976, The Pamunkey Project Phases I and II, The APE. Experimental Archaeology Papers Vol. 4. Department of Sociology and Anthropology, Virginia Commonwealth University, Richmond, 456 p.

Callahan, E.H. 1979, The basics of biface knapping in the Eastern Fluted Point tradition. A manual for flintknappers and lithic analysts. Archaeology of Eastern North America, 7(1): 1-180.

Callahan, E.H. 1979, Craftsman. Concluding the Crabtree interview. Flintknappers' Exchange, 2(3): 22-26.

Callahan, E.H. 1979, Craftsman. Don Crabtree. Flintknappers' Exchange, 2(1): 27-34.

Callahan, E.H. 1979, Craftsman. Don Crabtree. Flintknappers' Exchange, 2(2): 8-13.

Callahan, E.H. 1980, Craftsman. Bo Madsen. Flintknappers' Exchange, 3(2): 20-24.

Callahan, E.H. 1980, Craftsman. Gene Titmus. Flintknappers' Exchange, 3(1): 19-25.

Callahan, E.H. 1980, Spatial Organization of the Work Areas of Three Contenporary Flintknappers. Bulletin - Archeological Society of Virginia, 35(2): 101-108.

Callahan, E.H. 1981, Danish Dagger A-10198. Flintknappers' Exchange, 4(2): 11-14.

Callahan, E.H. (1981). The Maturation of Experimental Archaeology: A Critical View. presented at the Experimental Archaeology: The Old and the New. Second International Work Seminar in Lithic Technology, 6 August 1981, Lejre Research Center, Lejre, Denmark.

Callahan, E.H. 1981, Pamunkey Housebuilding: An Experimental Study of Late Woodland Construction Technology in the Powhatan Confederacy. Unpublished Ph.D. dissertation thesis at Catholic University of America, Washington D.C., 538 p.

Callahan, E.H. 1982, An interview with flintknapper Jacques Pelegrin. Contract Abstracts, 3(1): 62-70.

Callahan, E.H. 1984, I hate to bicker, but...: A study of microblade cores with obtuse platform angles. Lithic Technology, 13(3): 84-97. doi:10.1080/01977261.1984.11720855

Callahan, E.H. 1984, A Successful Test Model of the Type IV Danish Dagger. Flintkapping Digest, 1(10): 2-6.

Callahan, E.H. 1985, Experiments with Danish Mesolithic Microblade Technology. Journal of Danish Archaeology, 4: 23-29. doi:10.1080/0108464X.1985.10589933 
Callahan, E.H. 1985, The Fintknapping Industry of Eben-Emael. Quarterly Bulletin Archeological Society of Virginia, 40(2-3): 108-111.

Callahan, E.H. 1985, Flintknapping Flash Cards. Pressure Flaking of Flakes. Piltdown Productions, Lynchburg, 20 p.

Callahan, E.H. 1987, Anatomy of Decision. In: Flintknapping: An Emic Perspective (Harwood, R.J., Atwood, E. \& Bailey, R., Eds.), Harwood Archaeology, Palmdale: p. $18-23$.

Callahan, E.H. 1987, An Evaluation of the Lithic Technology in Middle Sweden During the Mesolithic and Neolithic. Aun Vol. 8. Societas Archaeologica Upsaliensis, Uppsala, 72 p.

Callahan, E.H. 1987, Metallic Powder as an Aid to Stone Tool Photography. American Antiquity, 52(4): 768-772.

Callahan, E.H. 1987, Primitive Technology: Practical Guidelines for Making Stone Tools, Pottery, Basketry, etc. The Aboriginal Way (1st ed.). Piltdown Production, Lynchburg, $25 \mathrm{p}$.

Callahan, E.H. 1993, Experimentell arkeologi i USA idag. Forntida Teknik, 2: 24-27. (in Swedish) ("Experimental Archeology in the USA Today")

Callahan, E.H. 1994, A Mammoth Undertaking. Bulletin of Primitive Technology, 7: 23-39.

Callahan, E.H. (1995). The Cahokia Pit House Project: A Case Study in Reconstructive Archaeology.Unpublished manuscript, Flagstaff, Arizona.

Callahan, E.H. 1995, What is Experimental Archaeology. Newsletter of Primitive Technology, $1: 3-5$.

Callahan, E.H. 1996, The Bipolar Technique: The Simplest Way to Make Stone Tools for Survival. Bulletin of Primitive Technology, 12: 16-20.

Callahan, E.H. 2000, Experiments with Danish Mesolithic Microblade Technology. Bulletin of Primitive Technology, 20: 62-68.

Callahan, E.H. 2000, What is Traditional Flintknapping? Bulletin of Primitive Technology, 20: 11 .

Callahan, E.H. 2006, Neolithic Danish daggers: An experimental peek. In: Skilled Production and Social Reproduction. Aspects on Traditional Stone Tool Technologies (Apel, J. \& Knutsson, K., Eds.), Uppsala University, Societas Archaeologica Upsaliensis (SAU) \& The Department of Archaeology and Ancient History, Uppsala: p. 115-129.

Callahan, E.H. 2008, Old Rag Archeology: Experimentation and Excavation. Society of Primitive Technology Publications. Schiele Museum of Natural History, Rexburg, ID, $839 \mathrm{p}$.

Callahan, E.H. 2010, Flake Removal Sequence and Cultural Inference. A Solutrean Perspective. In: Experiments and Interpretation of Traditional Technologies: Essays in Honor of Errett Callahan (Nami, H.G., Ed.), Ediciones de Arqueología Contemporánea, Buenos Aires: p. 561-659.

Callahan, E.H. \& Apel, J. 2011, The Flint Daggers of Denmark. Vol. 1 (1st ed.). Piltdown Productions, Lynchburg, $32 \mathrm{p}$. 
Callahan, E.H. 2013, The basics of biface knapping in the Eastern Fluted Point Tradition: A manual for flintknappers and lithic analysts (5th ed.). Piltdown Productions, Lynchburg, 213 p. URL: http://www.thebasicsbycallahan.com/

Callahan, E.H. 2016, Neolithic Danish Daggers. Volume 2. A Manual for Flintknappers and Lithic Analysts. Piltdown Productions, Lynchburg, 314 p.

Callahan, E.H. 2019, Errett Callahan Home Page. Retrieved 21 August 2019.

URL: http://www.errettcallahan.com/

\section{References cited in this biography}

Buck, G., (director), 2019, Memories of Errett Callahan. Running time: 6 min, $21 \mathrm{sec}$.

URL: https://www.youtube.com/watch?v=o1vt4XxmDqY

Callahan, E.H. 2019, Callahan Knives. Retrieved 21 August 2019.

URL: http://errettcallahan.com/knives

Coles, J. 1979, Experimental Archaeology. Academic Press, New York, 274 p.

Nami, H.G. (Ed.) 2010, Experiment and Interpretation of Traditional Technologies: Essays in Honor of Errett Callahan. Ediciones de Arqueología Contemporánea, Buenos Aires, $660 \mathrm{p}$.

Technology, S.o.P. 2019, Society of Primitive Technology Home Page.

URL: http://primitive.org/

the Digital Archaeological Record 2019, Errett Callahan. Center for Digital Antiquity, Arizona State University, Tempe, AZ. Retrieved 21 August 2019.

URL: https://core.tdar.org/browse/creators/54020/errett-callahan

Watts, S. 1997, The Fire Watchers: a Tribute to Errett Callahan. Bulletin of Primitive Technology, 14(Fall).

West, K. 2007, Biography of Errett Callahan. Retrieved 21 August 2019.

URL: http://errettcallahan.com/ 